\title{
UM ESTUDO SOBRE A GESTÃO DE MARCA DA EMPRESA NEW HOLLAND CONSTRUCTION
}

\author{
Thuane Christine Coelho MAGALHÃES ${ }^{1}$ \\ Marcelo Aureliano Monteiro de ANDRADE ${ }^{2}$ \\ Marlusa de Sevilha GOSLING ${ }^{3}$ \\ Iury Teixeira de Sevilha GOSLING ${ }^{4}$
}

\begin{abstract}
${ }^{1}$ Administradora de Empresa (UFMG). thuane.magalhaes@ outlook.com
${ }^{2}$ Publicitário (PUC-MG), Mestre e Doutor em Administração (UFMG). Professor do curso de Administração da UninCor. aureliano.marcelo@yahoo.com.br

${ }^{3}$ Analista de Sistemas, Mestre e Doutora em Administração (UFMG). Professora Associada da UFMG. mg.ufmg@gmail.com

${ }^{4}$ Administrador (Unicesumar). Pesquisador do NEECIN - TUR (UFMG). iurygosling@gmail.com
\end{abstract}

Recebido em: 18/03/2017 - Aprovado em: 26/06/2017 - Disponibilizado em: 01/07/2017

\begin{abstract}
RESUMO
Nas últimas décadas, tem-se percebido grande proliferação de marcas fortes. Nesse contexto, é importante avaliar e analisar as questões relativas às marcas e o que têm sido feito para gerir esse artigo intangível. Este trabalho apresenta um estudo sobre a gestão de uma marca no mercado Business to Business (B2B), a partir de uma situação real. O assunto se mostra importante, uma vez que em um mercado extremamente competitivo como no B2B, oferecer um produto ou serviço de qualidade não é o suficiente para ganhar destaque. Além disso, a literatura de marcas ainda é muito voltada ao contexto Business to Consumer. Este estudo teve como objetivo analisar as estratégias utilizadas pela empresa New Holland Construction para fazer a gestão da marca no Brasil nos últimos anos. A pesquisa é de natureza exploratória e aconteceu por meio de entrevistas com gestores responsáveis pela gestão da marca, a fim de se analisar as estratégias para o posicionamento e a imagem da marca no mercado. Percebeu-se que há um trabalho extenso de gestão de marca na empresa e que as ações, em todas as esferas do Mix de Marketing, são coerentes aos aspectos recomendados pela literatura para o contexto B2B.
\end{abstract}

Palavras-chave: Marca. Gestão de Marca. Mercado B2B. Mix de Marketing. Marketing de Relacionamento.

\begin{abstract}
In recent decades, it has seen great proliferation of strong brands. In this context, it is important to evaluate and analyze issues about brands and what have been made to manage this intangible item. This paper presents a study on the management of a brand in the market Business to Business (B2B), from a real situation. The subject proves important, since in an extremely competitive market like in B2B, offer a quality product or service is not enough to gain prominence. In addition, the literature's brand is still very focused on Business to Consumer context. This study aimed to analyze the strategies used by the company New Holland Construction to manage it's brand in Brazil in recent years. The research is exploratory in nature and happened through interviews with managers responsible for brand management, in order to analyze the strategies for positioning and brand image in the market. It was noticed that there is an extensive work brand management in the company and that the actions, in all aspects of the Marketing Mix, are coherent with the literature for the B2B context.
\end{abstract}

Keywords: Brand. Brand Management. B2B Market. Marketing Mix. Relationship Marketing. 


\section{INTRODUÇÃO}

As corporações não vendem apenas os produtos ou serviços, junto com eles estão as marcas que as representam. Os avanços tecnológicos fazem com que os produtos concorrentes tenham características técnicas cada vez mais próximas e com qualidade semelhante, dessa forma, a diferenciação se dá pela marca e por todos os atributos tangíveis e intangíveis que a permeiam. A marca tem como uma das principais funções diferenciar e distinguir o produto de uma empresa de outros da mesma categoria, a fim de criar relações de fidelidade entre marca e consumidor (SCIASCI; GARCIA; GALLI, 2012). Conforme Vasquez (2007), quanto mais acirrado o mercado, mais é preciso construir uma marca forte, sólida e competitiva, para ir além das transações comerciais, conquistando a mente do consumidor.

É importante destacarmos a influência da marca no processo de decisão de compra. Para Silveira (2008), as marcas influenciam na decisão de compra, seja no mercado Business to Business (B2B) - em que as relações comerciais se dão entre organizações -, ou no mercado Business to Consumer (B2C) - realizado entre empresas e consumidor final -, uma vez que, em caso de dúvida, a conscientização da marca junto ao consumidor será determinante. $\mathrm{O}$ autor ainda afirma que a marca tem como um dos principais, senão o principal, propósitos influenciar a decisão de compra do consumidor. Dessa forma, um fator importante de influência na decisão de fidelidade de uma marca é a experiência de uso, base para sua formação (LEITE; WINCK; ZONIN, 2012).

Para Vásquez (2007), a identidade é a base da marca, pois os consumidores associam uma série de sentimentos e relações sociais transmitidas pela marca que os levam a realizar transações com a empresa. Conforme dito por Leite, Winck e Zonin (2012), a imagem de marca é gerada por meio de associações, assim, o consumidor compara a marca a outros atributos favoráveis e desfavoráveis. Quanto mais fortes e favoráveis os atributos relacionados à marca, mais distante das concorrentes ela estará e, portanto, mais difícil de ser copiada.

A imagem de marca corresponde a um conjunto de crenças sobre uma marca em relação aos atributos do produto, representando como os consumidores veem a marca, enquanto que as associações são ligadas à imagem, podendo se referir aos atributos do produto, benefícios, preço, qualidade, uso, estilo de vida, classe de produto, concorrentes, origem, além de atributos e aspectos intangíveis (AAKER, 1998). Assim, não apenas a comunicação de marketing constitui a imagem da marca perante os públicos, mas todos os aspectos 
que de alguma maneira formulam o que o consumidor pensa sobre a marca.

A construção de uma marca, portanto, e segundo Toni et al. (2014), leva tempo e despende muito recurso. Para ser efetiva na transmissão do comprometimento da organização com a qualidade dos atributos do produto, necessita de comunicação adequada, para demonstrar claramente o seu posicionamento, visando adquirir um vínculo emocional com os consumidores. Faz-se necessário posicionar a marca corretamente no mercado, a fim de contribuir para que o público-alvo consiga diferenciar as empresas concorrentes e escolher a que lhe demonstre maior valor agregado (SCIASCI; GARCIA; GALLI, 2012).

A gestão correta da marca, portanto, é fator determinante, uma vez que esta tem a responsabilidade de criar e fazer a manutenção dos atributos funcionais e simbólicos com o objetivo de gerar vantagem competitiva à organização (LEITE; WINCK; ZONIN, 2012). É importante nesse contexto entender o conceito de Branding, visando ao aprofundamento futuro no assunto. Conforme Limas (2009), Branding é o que entendemos como análise, reposicionamento, criação e gestão das marcas. Dessa forma, o Branding está relacionado ao início da Organização, à estratégia admitida, e à cultura e posicionamento adquiridos pela mesma.

Salienta-se que um dos pontos importantes de estudos de marcas é o seu uso no âmbito Business to Business

(KELLER ET AL., 2007). KELLER E MACHADO (2007) reforçam que, apesar da grande ênfase na literatura de marcas ao contexto B2C, o reforço de marca em situações B2B pode ser uma ótima oportunidade para as organizações dessa natureza, o que salienta a necessidade de se construir e consolidar cada vez mais conhecimento teórico sobre o tema. Neste sentido, desenvolveu-se esta pesquisa a partir de uma das grandes marcas de equipamentos para construções do Brasil, a New Holland Construction. Atualmente, a marca tem atuação em todos os Estados brasileiros, com quarenta e oito concessionários. Possui gama completa de equipamentos de construção (retroescavadeiras, motoniveladoras, escavadeiras hidráulicas, tratores de esteira, manipuladores telescópicos, pás carregadeiras e mini carregadeiras), com 52 produtos fabricados na fábrica de Contagem. A New Holland possui cerca de $17 \%$ de Market share, ocupando a terceira colocação no mercado brasileiro.

Levando em consideração todas as esferas relacionadas anteriormente acerca das definições de marca, como importância financeira no âmbito organizacional, influência exercida, imagem, identidade, posicionamento adequado das marcas e marcas globais, além de indagações sobre comunicação mercadológica, composto de marketing e gestão de marca, a pergunta de 
pesquisa proposta foi a seguinte: Quais as estratégias utilizadas pela empresa New Holland Construction para fazer a gestão da marca, no Brasil, a partir de 2005 ?

Dessa forma, buscou-se responder como a New Holland Construction desenvolve a gestão da marca. Por ser uma empresa multinacional, de atuação efetiva em diversos países do mundo, o estudo visa compreender as ações de gestão da marca realizadas desde a mudança de Fiatallis para New Holland, no ano de 2005, para consolidar a imagem da marca no mercado brasileiro, visando conquistar a confiabilidade da empresa na mente dos consumidores.

\section{REFERENCIAL TEÓRICO}

\subsection{Marca}

De acordo com Kotler (2000, p. 426): "Uma marca é um nome, termo, símbolo, desenho - ou uma combinação desses elementos - que deve identificar os bens ou serviços de uma empresa ou grupo de empresas e diferenciá-los dos da concorrência.". Uma marca tem duas funções a cumprir. A primeira delas é criar uma proposta de valor relevante e convincente, já a segunda é fazer essa proposta ganhar credibilidade e confiança no mercado, principalmente quando há risco para o consumidor (AAKER

$\mathrm{e}$ JOAQUIMSTHALER, 2002).

As marcas agregam outras dimensões a um produto para diferenciá-lo de outros produtos concorrentes, que satisfazem a uma mesma necessidade. Essas dimensões podem ser tanto racionais e tangíveis, quanto simbólicas, sentimentais e intangíveis, pois o que diferencia um produto de uma marca conhecida para outro similar de marca desconhecida é a soma da percepção e dos sentimentos que o consumidor tem em relação aos atributos oferecidos e o desempenho do produto em relação à marca, seu significado $\mathrm{e}$ a associação da empresa com a marca (KELLER, 2007; 1998).

De acordo com Aaker (1996), o valor de uma marca pode ser mensurado a partir de cinco elementos, que são: lealdade à marca, reconhecimento, qualidade percebida, conjunto de associações e outros ativos. Esses elementos acrescentam benefícios aos clientes, por garantir uma melhor interpretação das informações recebidas da marca, aumentam a confiança na decisão de compra e a satisfação de uso. Por outro lado, para a empresa esses elementos proporcionam valor, por aumentarem a margem de lucro, a eficiência e eficácia dos programas de marketing, vantagem competitiva e lealdade à marca.

Nesse sentido, tornou-se importante o uso do conceito de Brand Equity, ou valor de marca, para as investigações e análises. Aaker (1998) define Brand Equity como um conjunto de ativos que pode ser o conhecimento do nome, consumidores leais, qualidade percebida, associações e fidelidade, 
que se liga ao produto ou serviço em oferta. $\mathrm{O}$ autor acrescenta que para os acionistas, o Brand Equity deve ser também interpretado como componente fundamental do valor monetário e comercial da marca para o negócio.

Aaker (1991) acredita que o reconhecimento do papel e do valor da marca como ativo das organizações obriga o desenvolvimento de estratégias de gestão e potencialização do seu valor. Grönroos (2007), na mesma linha, afirma que gerir uma marca prosseguindo uma abordagem relacional exige, em primeiro lugar, o reconhecimento de que a principal tarefa passa por uma gestão adequada do processo de interação entre a marca e os seus clientes, para que se crie uma relação favorável entre ambas as partes. Por outro lado, as opções em termos dos sinais de identidade da marca, bem como as ações no âmbito do mix de marketing que venham a se realizar, não são mais do que elementos de suporte que facilitam a criação de um envolvimento positivo com a marca.

Conforme já destacado, há muita ênfase na literatura de marcas para situações B2C, mas existe necessidade de se desenvolver e disseminar estudos também no contexto B2B. Silveira (2008) afirma que as marcas no mercado organizacional podem também ter muito prestígio e o maior exemplo disso vem da marca GE - General Electric, a qual ocupou o segundo lugar no ranking 2008, realizado pelo Millward Brown Optimor, das marcas mais valorizadas do mundo, perdendo apenas para o Google.

Kotler e Pfoertsch (2008) citam as mais importantes funções da marca no mercado B2B, reveladas por um estudo da McKinsey \& Company em conjunto com o Marketing Center Muenster (MCM) ao pesquisar e analisar a importância e relevância das marcas em diversos mercados B2B alemães: a) Incrementar a eficiência da informação; b) Reduzir os riscos; c) Criar benefício de valor agregado/imagem. A pesquisa ainda revela que dentre as funções, a identificada como mais importante para $45 \%$ dos executivos entrevistados é a redução de riscos. Apenas 14\% consideraram o benefício do valor agregado/imagem como o mais importante. É possível observar a diferença da importância da marca para o mercado B2C, no qual o benefício de valor agregado/imagem é o mais importante para $40 \%$ dos entrevistados. Ainda de acordo com Kotler e Pfoertsch (2008), no mercado B2B as marcas estão entre as melhores soluções, nas quais as empresas podem apostar para reforçar a sua competitividade, pois elas representam um meio eficiente e poderoso de distinção de uma oferta em meio aos concorrentes. As marcas ainda dificultam a crescente proliferação de produtos e serviços similares: Com o 
objetivo de reduzir os riscos, os compradores estão cada vez mais passíveis às marcas.

A empresa New Holland Construction está inserida no mercado organizacional, portanto B2B. Dessa forma, foi preciso contextualizar as aplicações das marcas neste mercado, bem como identificar e expor a necessidade de gerenciá-las adequadamente, visando adquirir vantagem competitiva.

\subsection{Composto de Marketing}

O composto de marketing também é conhecido como Mix de Marketing ou "4Ps". O composto de marketing é definido por Kotler e Armstrong (2000, p. 37) como sendo "o grupo de variáveis controláveis de marketing que a empresa utiliza para produzir a resposta que deseja no mercadoalvo". Para Belch e Belch (1998), Guenzi e Troilo (2006), o composto de marketing pode ser definido da seguinte maneira: 1) o produto é composto por características, variedade, qualidade, nome da marca, design, embalagens, tamanhos, serviços, garantias, devoluções, entre outros; 2) o preço refere-se a descontos, prazos de pagamento, condições de crédito, entre outros; 3) a praça ou ponto de venda diz respeito aos canais de distribuição, distribuição do estoque, transporte, armazenagem, entre outros; e 4) a promoção entende-se como a venda pessoal, propaganda, promoção de vendas, publicidade, relações públicas, marketing direto, dentre outras ações. Salienta-se que o composto de marketing, especialmente no âmbito da Promoção, ou Comunicação de Marketing, foi de vital importância para a elaboração do instrumento de pesquisa deste estudo, para identificar características e aplicações do preço, da praça, do produto e da promoção que são exercidos pela empresa, visando responder à pergunta de pesquisa proposta.

\section{METODOLOGIA}

O presente estudo caracteriza-se como uma pesquisa exploratória, pois tem como objetivo familiarizar-se com um assunto ainda pouco conhecido e pouco explorado (MALHOTRA, 2004; GIL, 1999). No que se refere à abordagem, caracteriza-se como qualitativo (FLICK, 2014), pois se baseou em entrevistas semi-estruturadas. Maanen (1979) diz que a pesquisa qualitativa tem por objetivo traduzir e expressar o sentido dos fenômenos no mundo social; trata-se de reduzir a distância entre indicador e indicado, entre teoria e dados, entre contexto e ação. Segundo Malhotra (2004) "é preciso efetuar pesquisas qualitativas para que se possa compreender o problema, pois este tipo de pesquisa apresenta uma forma não estruturada, que permite interpretar a 
subjetividade do sujeito, que tem uma relação com a realidade."

Foi utilizado para escolha dos entrevistados o conceito de "corpus" de pesquisa, que, segundo Bauer (2002), é um recorte arbitrário de elementos que o pesquisador define para que, ao aplicar sobre ele uma metodologia, possa atingir o objetivo. Logo, a construção do corpus é uma escolha do pesquisador, que deve ser justificada no trabalho. Dessa forma, escolheu-se convenientemente o Gerente de Marketing de Produto, a Gerente de Dealer Development, a Gerente de Brand Marketing e a Analista Sênior de Brand Marketing, visto que estes gestores são os responsáveis pela gestão da marca New Holland e, portanto, teriam maior conhecimento para responder às perguntas da entrevista e contribuir de forma mais efetiva para este estudo.

O principal instrumento utilizado para a coleta de dados foi entrevista semiestruturada, porém, também foram utilizadas as técnicas da pesquisa documental, de registros disponibilizados pela empresa, visando apresentar a história da empresa e como ela está no momento atual. A pesquisa documental, segundo Fachin (2001): “consiste na coleta, classificação, seleção difusa e na utilização de toda espécie de informação, compreendendo também as técnicas e métodos que facilitam a sua busca e identificação [...]". Elaborou-se o questionário com base em dois conteúdos principais:

composto de marketing e características de mercado, e comunicação mercadológica. Contemplou-se, além disso, questões relativas a estratégias de relacionamento. As perguntas relativas ao composto de marketing basearamse nos seguintes autores: Pride e Ferrell (2000), Belch e Belch (1998), Guenzi e Troilo (2006), Fonseca (2008), Kotler e Roberto (1992), Churchill e Peter (2000). As perguntas relativas à comunicação mercadológica basearam-se nos seguintes autores: Vásquez (2007), Kotler (2000), Costa e Crescistelli (2003), Colauto, et al (2006).

Abaixo um quadro apresentando as perguntas propostas separadas em composto de marketing e características do mercado, e comunicação mercadológica:

Quadro 1 - Questionário Proposto

\begin{tabular}{|l|}
\hline Composto de Marketing e Características de \\
Mercado
\end{tabular}


- Na sua opinião a empresa consegue manter um relacionamento próximo com os clientes?

- A empresa realiza eventos para atingir o público-alvo?

- A empresa investe em quais tipos de propagandas?

- A empresa possui assessoria de imprensa?

- A empresa possui algum tipo de atendimento personalizado a clientes? E o pós venda?

- A empresa utiliza recursos como mala direta, encartes e e-mail marketing?

- A empresa realiza ações de incentivo ao cliente? (desconto de preço, entrega de amostra gratuita para o consumidor testar o produto, programas de fidelidade, sorteio de produtos).

Fonte: Elaborado pelos autores.

Para a análise dos dados, foi feita uma análise de conteúdo das entrevistas. Para isso, fez-se a classificação de conceitos, separando os assuntos que foram abordados nas entrevistas. Além disso, foi feita a separação das respostas em quatro categorias distintas: 1) percepção dos entrevistados com relação à empresa frente ao mercado; 2) Percepção dos entrevistados sobre o preço e diferenciais oferecidos pelo produto; 3) relacionamento da marca com o concessionário e com o cliente final, e; 4) instrumentos de comunicação utilizados pela empresa, Como mostra o quadro abaixo:

QUADRO 2 - Divisão em Categorias

\begin{tabular}{|c|c|c|}
$\begin{array}{c}\text { Percepção dos } \\
\text { entrevistados com } \\
\text { relação à empresa frente } \\
\text { ao mercado. }\end{array}$ & $\begin{array}{c}\text { Percepção dos } \\
\text { entrevistados sobre o } \\
\text { preço e diferenciais } \\
\text { oferecidos pelo produto. }\end{array}$ \\
\hline Qual a proporção & $\bullet$ & Como os \\
do número de & produtos da New \\
clientes que & Holland se \\
representam os & posicionam no \\
lucros obtidos & mercado para se \\
pela empresa? & diferenciar dos \\
Existe alguma & concorrentes \\
segmentação de & (características \\
\hline
\end{tabular}

\begin{tabular}{|c|c|}
\hline 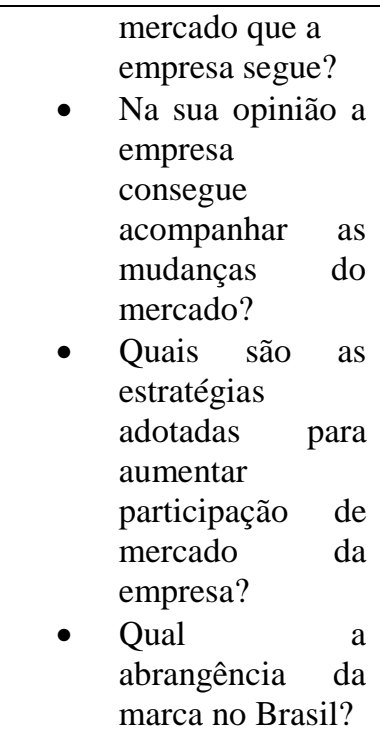 & $\begin{array}{l}\text { do produto)? } \\
\text { Na sua opinião, } \\
\text { os preços } \\
\text { exercidos pela } \\
\text { empresa } \\
\text { refletem o valor } \\
\text { que é oferecido } \\
\text { ao cliente? } \\
\text { Como o cliente } \\
\text { percebe isso? }\end{array}$ \\
\hline $\begin{array}{c}\text { Relacionamento da } \\
\text { empresa com o } \\
\text { concessionário e com o } \\
\text { cliente final. }\end{array}$ & $\begin{array}{l}\text { Instrumentos e formas } \\
\text { de comunicação } \\
\text { utilizadas pela empresa. }\end{array}$ \\
\hline $\begin{array}{l}\text { Qual ou quais as } \\
\text { ferramentas de } \\
\text { relacionamento } \\
\text { são usadas com } \\
\text { os clientes? } \\
\text { (Consideramos } \\
\text { as } \\
\text { concessionárias } \\
\text { como clientes ou } \\
\text { como parceiros?) } \\
\text { (Quais as } \\
\text { ferramentas } \\
\text { utilizadas com os } \\
\text { concessionários e } \\
\text { quais as } \\
\text { ferramentas } \\
\text { utilizadas com } \\
\text { cliente final?) } \\
\text { Na sua opinião a } \\
\text { empresa } \\
\text { consegue manter } \\
\text { um } \\
\text { relacionamento } \\
\text { próximo com os } \\
\text { clientes? } \\
\text { (Consegue } \\
\text { manter um } \\
\text { vínculo? Que } \\
\text { tipo de vínculo?) } \\
\text { A empresa } \\
\text { realiza eventos } \\
\text { para atingir o } \\
\text { público-alvo? }\end{array}$ & $\begin{array}{l}\text { A empresa } \\
\text { investe em quais } \\
\text { tipos de } \\
\text { propagandas? } \\
\text { A empresa } \\
\text { possui assessoria } \\
\text { de imprensa? } \\
\text { A empresa } \\
\text { possui algum } \\
\text { tipo de } \\
\text { atendimento } \\
\text { personalizado a } \\
\text { clientes? E o pós } \\
\text { venda? } \\
\text { A empresa } \\
\text { utiliza recursos } \\
\text { como mala } \\
\text { direta, encartes e } \\
\text { e-mail } \\
\text { marketing? } \\
\text { A empresa } \\
\text { realiza ações de } \\
\text { incentivo ao } \\
\text { cliente? } \\
\text { (desconto de } \\
\text { preço, entrega de } \\
\text { amostra gratuita } \\
\text { para o } \\
\text { consumidor } \\
\text { testar o produto, } \\
\text { programas de } \\
\text { fidelidade, } \\
\text { sorteio de } \\
\text { produtos). }\end{array}$ \\
\hline
\end{tabular}

Fonte: Elaborado pelos autores. 
Após o levantamento dos dados secundários e reunião das entrevistas, as informações foram estruturadas seguindo a proposta do estudo e atentando para que todas as informações relevantes fossem descritas. Verificou-se, portanto, o grau de coerência na gestão da marca, especialmente sobre os aspectos comunicados e entregues pela organização.

Com isso, fez-se a comparação das informações da atividade prática com as descrições do referencial teórico e, dessa maneira, foram baseadas a análise e conclusão dos resultados.

\section{APRESENTAÇÃO E ANÁLISE DOS DADOS}

\subsection{A Empresa Frente ao Mercado}

Para esta categoria, foram levantadas questões relativas à proporção de clientes que representam a maior parte das vendas, segmentação de mercado, adaptação às mudanças do mercado, participação e abrangência de mercado.

Primeiramente, procurou-se saber dos entrevistados se a empresa percebe certa proporção entre o número de clientes e a representação das vendas. Foi possível perceber através das respostas oferecidas que existe cerca de $20 \%$ de clientes que representam $80 \%$ das vendas obtidas - de acordo com a literatura (KOTLER, 2000).

Esses clientes estão alocados em três principais segmentos, que são: construção, com foco em infraestrutura; rental; e Governo. Como dito pelo Gerente de Marketing de Produto:

Os três mais importantes
segmentos são construção,
rental e Governo, depois
vêm os pequenos como
indústria, agrícola e
florestal, que não tem uma
importância rãa
significativa. Então eu
diria que a proporção de
80\% dos lucros para 20\%
dos clientes incluiriam os
grandes desses três
principais segmentos.

Questionados sobre a segmentação exercida pela empresa, verificou-se que a firma trabalha com a segmentação por atuação, sendo no setor de construção, infraestrutura, indústria, construção, florestal, agrícola, rental e Governo, focando seus esforços principalmente nos setores de maior participação, conforme citado acima (construção, rental ${ }^{1}$ e Governo), mas buscando novas possibilidades nos segmentos de menor atuação, como no setor agrícola.

Esses três segmentos são
os mais importantes para a
New Holland, mas nós
temos dado um foco
enorme em agrícola,
porque a gente tem uma
boa atuação nesses três
segmentos (construção,
rental e Governo), precisa
dar manutenção, encontrar
novos clientes, mas que a
gente está sempre
navegando e os demais que
tem um valor menos
importante são onde a 
gente pode encontrar novos clientes. No mercado agrícola, pelo fato do grupo ter a marca New Holland Agrícola, é uma oportunidade, fora que $\mathrm{o}$ mercado agrícola é muito grande (Gerente de Marketing Produto).

Sobre as mudanças de mercado, foi perguntado a respeito da flexibilidade por parte da empresa para acompanhá-las. Verificou-se que a New Holland mantém uma área especializada em inteligência de mercado, além de estar ligada a entidades que fornecem análises do mercado de equipamentos de construção, como a Sobratema. Percebeu-se enorme capacidade de adaptação às mudanças mercadológicas, reagindo às demandas do mercado mais rapidamente do que as marcas concorrentes. Diversas situações foram citadas, expondo adequações feitas nas máquinas para atender a funções às quais elas não atenderiam, conquistando novos clientes e até mesmo mercados diferentes. Novamente, os entrevistados exploraram as ações realizadas focando o mercado agrícola, uma vez que na atual conjuntura político-econômica os principais segmentos explorados pela empresa estão se mostrando fortemente debilitados e com pouco investimento.

[...] Então falando de acompanhar mercado, nós já fizemos três lançamentos de máquinas esse ano, num ano que todo mundo começou com o pé no freio, porque é um ano de crise, todo mundo comentando certa instabilidade políticoeconômica e no nosso caso, a gente já chega com três lançamentos de cara. Outra coisa que é importante ressaltar aqui é como a gente busca aplicações diferenciadas para a máquina de construção, por exemplo, o mercado agrícola no Brasil é absurdamente grande e tem uma demanda enorme, porque pode ter crise, mas as pessoas não param de comer, se não param de comer a gente não para de plantar e as nossas máquinas de construção tem várias aplicações dentro do mercado agrícola e quando tem uma aplicação que possa ser melhorada através de um implemento na máquina a gente corre atrás disso pra apresentar uma solução pronta pro mercado, de acordo com o que ele está exigindo, ou seja, capacidade de adaptação eu considero uma das melhores do mercado (Analista Sênior de Brand Marketing).

\section{O Gerente de Marketing Produto} ressalta questões históricas de mudanças na estratégia da marca que explicam a necessidade de reagir mais rapidamente ao mercado: 
vida sempre foi mais difícil, não sei se por causa disso, a gente se adapta muito rápido e não fica chorando as mágoas. Qualquer novidade, ou modificação que precisa ser feita, eu sinto uma dificuldade das outras brands de se adaptar e para a New Holland é muito rápido.

Atrelado a isso, questionou-se sobre as estratégias adotadas para aumentar participação de mercado da empresa. Mais uma vez, o destaque foi dado ao que se percebeu como sendo a principal estratégia atual de atuação no mercado, mantendo o foco em um nicho ainda pouco explorado segmento agrícola - para aumentar as vendas e a participação de mercado da empresa. Novas questões surgiram, como algumas adaptações feitas para diminuir o custo da máquina, porém, sem perder em desempenho, substituindo perfumarias como tapetes e bancos. Além disso, ressaltaram-se também os eventos que são realizados para demonstração de equipamentos, como participação em feiras e também visitas realizadas à fábrica da empresa, estratégias utilizadas para cativação e captação de novos clientes. Conforme elucidado pela Analista Sênior de Brand Marketing:

Então, porque não fazer uma máquina que possa chegar ao mercado num custo mais competitivo e que tenha a mesma qualidade que a New Holland sempre teve? É o caso, por exemplo, da máquina que a gente vai fazer o lançamento esse ano. Ou seja, aumentar a participação de mercado nada mais é do que estar atento à movimentação do mercado, estar atento à concorrência sim, mas tentar propor produtos que sejam mais altos em qualidade e que possam atender a aplicações muito diferentes, que eu acho que é o que a gente tenta fazer por aqui.

No que diz respeito à participação no mercado atual de máquinas de equipamentos de construção, a marca está na terceira posição. Destrinchando o mercado em máquinas pesadas, a empresa se encontra na segunda posição, já em máquinas leves, permanece em terceiro. Quanto à abrangência da marca no mercado brasileiro, foi dito que a m stionados sobre a diferenciação existente nos produtos da New Holland, destacou-se que a marca tem um grande know-how de tecnologia e inovação, vanguarda e confiabilidade. Além disso, identificou-se que a empresa é forte no mercado com a linha de máquinas pesadas e está investindo na criação de novas máquinas para concorrer com competidores que tinham hegemonia em determinado tipo de máquina. Foi relatado pelos entrevistados que em máquinas de construção a preocupação é com a qualidade, performance, produtividade e consumo, ou seja, carregar alto volume de material consumindo pouco combustível. Destacado como artigo de grande importância também o pós-vendas realizado pelos concessionários, no momento em que a máquina estraga, 
fornecendo peças e serviços de apoio aos proprietários das máquinas.

O que eu observo da New Holland, até no último comparativo que a gente foi fazer com os concorrentes do D180C (trator hidrostático, na classe de vinte e duas toneladas), o pessoal fala que a máquina tem design, é mais bonita e a preocupação não é só com a beleza, porque essa beleza está atrelada a características, você vê que tem uma visibilidade melhor porque o capô não é "quadradão", ele tem as linhas que dão uma visibilidade melhor, você tem melhor acesso à manutenção diária, que é uma coisa muito importante no equipamento de construção. Então, o grande diferencial é isso: a gente alia tudo àquilo que já é importante e é básico ter, com uma característica visual agradável, mas que não é só agradável, tem o intuito de dar performance e criar alguma melhoria no equipamento (Gerente de Marketing Produto).

Os entrevistados ainda relataram que existe uma pesquisa anual de satisfação do cliente e no resultado de 2014, avaliando os dados de 2013, a marca ganhou na América latina no quesito Índice de Satisfação Espontânea de Produto e Benchmarking de Mercado, ou seja, a empresa possui o melhor produto do mercado.

Com relação ao preço, perguntou-se sobre a percepção dos entrevistados quanto ao valor oferecido versus o preço exercido pela marca. Percebeu-se, a partir das respostas dos gestores, que o preço não reflete o valor oferecido, uma vez que aliando a qualidade do equipamento, o pós-vendas e a imagem transmitida pela marca, o cliente recebe mais do que lhe é cobrado por isso. Isso acontece por uma estratégia da marca num momento de transição ocorrido em 2005, quando a marca Fiatallis foi substituída pala marca New Holland no Brasil. A marca New Holland ainda era desconhecida e foi preciso praticar preços inferiores para penetrar no mercado brasileiro, porém, hoje a marca já possui reconhecimento e os preços continuam defasados. Para o Gerente de Marketing de Produto, essa estratégia de preço precisa ser trabalhada ao longo do tempo, com muita cautela.

Outro fator importante para a Gerente de Brand Marketing foi a entrada dos chineses no mercado brasileiro que não possuem o chamado "custo Brasil". Devido a isso, todas as montadoras brasileiras tiveram que se adaptar a um patamar diferente em termos de preço. O Gerente de Marketing de Produto ainda relata que é possível inferir que o cliente também percebe essa defasagem, através do seguinte exemplo:

Eu acho que o cliente percebe isso. Nós tivemos alguns feedbacks dessa pesquisa, onde alguns pontos destoaram. Um cara disse assim: "ah, os equipamentos da New Holland são muito baratos". Quando o cara fala isso e ele conhece a 
marca e sabe que nós estamos aqui há sessenta e cinco anos é porque ele sabe que nosso produto tem qualidade, tem pósvendas e ele realmente acha barato quando compara com os outros porque o chinês é muito barato também, só que quem comprou uma máquina chinesa há três anos, quando estava no boom de equipamento asiático, hoje ele chora lágrimas de sangue porque o equipamento dele não tem mais valor nenhum, o equipamento não trabalhou e não teve pós-vendas.

\subsection{Relacionamento com o cliente}

No que concerne ao relacionamento com o cliente, foi perguntado se a empresa mantém um relacionamento próximo e quais as ferramentas de relacionamento utilizadas. Percebeu-se que entre a empresa e o cliente final estão localizados os concessionários, que fazem a intermediação entre os extremos. Dessa forma, as respostas obtidas tratam dos concessionários e dos clientes finais. Os concessionários são considerados parceiros da empresa e todas as estratégias de relacionamento passam pelo concessionário para chegar ao cliente final.

Ficou claro e evidente em todas as respostas obtidas que a empresa se preocupa em manter um vínculo com os clientes, sendo o relacionamento a maior referência da marca e o principal diferencial com relação aos concorrentes. Essa característica foi herdada da antiga Fiatallis e continuou sendo praticada pela New Holland. Diversas ações de marketing de relacionamento são realizadas para fidelizar o cliente.

A Fiatalllis sempre fez
uma viagem anual pra
Itália com os principais
clientes. Então o cliente
Fiatallis já sabia que ia
viajar, aí chegava lá eles
conheciam a fábrica da
Ferrari, a fábrica da Fiat e
conhecia a Itália em si, o
que tinha tudo a ver com o
mundo Fiatallis, então isso
tudo fazia parte da vida
deles e tinha um valor
emocional, a marca
entrava na vida da pessoa
(Gerente de Dealer
Development).

Destacou-se que a New Holland realiza ações de marketing de relacionamento, pois percebe que isso cativa o cliente e converte em resultados comerciais. Por outro lado, para o cliente também é importante estar próximo da marca. Abaixo, foram elencados dois exemplos que demostram isso:

Quando, por exemplo, a
gente traz uma pessoa pra
fazer uma visita à fábrica,
já muda o relacionamento
do cliente com a gente e o
relacionamento do cliente
com o concessionário, fica
mais próximo. Eu já ouvi
cliente falando que não
compra da Caterpillar
porque já virou amigo do
concessionário. Então são
ações que são importantes
pra aproximar o cliente do
concessionário e da marca,
com isso a gente fideliza o
cliente (Gerente de Dealer
Development).

Isso já é um DNA da New Holland, sempre foi assim de ser muito próximo do cliente. Essa diferença é 
bem gritante quando a gente fala de um competidor como a Catterpillar, eu te falo isso porque nesse ultimo Yellow Day, quando nós fomos jantar, tinha um cliente que estava com o telefone da Caterpillar, aquele que não quebra e ele falou: "olha, a Caterpillar me deu isso aqui, só que eu nunca fui recebido numa fábrica da Caterpillar igual eu estou sendo recebido aqui por vocês". Eu já sabia disso, já tinha escutado de outros e esse é o mais recente. Isso eu acho um grande diferencial, a gente cuida disso e procura criar outras formas de relacionamento (Gerente de Marketing Produto).

A empresa mantém eventos como o "Yellow Day", onde o concessionário, em parceria com a empresa, seleciona um grupo de clientes para conhecer a fábrica da empresa, todo o processo de produção, além de conhecer a história e todos os produtos da marca, através de palestras e demonstrações, onde o próprio cliente pode testar algumas máquinas que ficam disponíveis e até mesmo fechar pedidos. E também o "Yellow Night", um evento noturno, com um formato mais social, com máquinas expostas, porém, diferente do "Yellow Day", em que as máquinas estão estáticas, com o objetivo mais de relacionamento do que de apresentação institucional e de produtos. Existe também o "Teste e Comprove", um programa de demonstração de máquina, no qual o cliente fica um tempo testando a máquina da empresa nas suas operações. Além disso, a empresa dá suporte aos eventos realizados pelos próprios concessionários.

A empresa possui o programa chamado "Clube Ouro", que está se transformando no "Yellow Club", um clube de relacionamento com os quarenta principais clientes da marca. Através desse clube é possível ter um relacionamento mais direto com estes clientes, direcionar ações mais específicas e acompanhá-los antes, durante e depois das compras realizadas, além de ser possível elencar esses clientes em categorias diferentes, de acordo com a interação que o cliente tem com a marca.

\subsection{Instrumentos de Comunicação}

Essa última categoria procura demonstrar quais as ferramentas que são utilizadas pela empresa para comunicação com o cliente, bem como identificar o discurso da marca e sua coerência com o restante do Mix de Marketing. Dessa forma, identificou-se que a empresa investe em várias frentes através do plano de mídia publicitária. Realizado anualmente, ele permite a entrada em veículos considerados prioritários, como mídias segmentadas, através de assessoria de imprensa, em jornais e revistas especializados na área de construção, mais focados na parte técnica que são direcionadas ao público alvo. Atua também na mídia corporativa, através das empresas do Grupo Fiat, além de atuar na mídia de massa, através do rádio, jornais, 
revistas e programas de televisão, como o programa Globo Rural, da emissora Globo, e o programa esportivo Linha de Passe, da emissora ESPN. Outros recursos de comunicação também são utilizados, como mala direta, encartes, e e-mail marketing.

O objetivo é o de tentar tornar a marca não popular, eu diria, porque o mercado de máquinas de construção não é um mercado popular, mas tentar tornar a marca mais reconhecida, uma marca mais massificada, pra você poder, mais pra frente falar "New Holland" e a pessoa falar "ah sim, máquinas de construção". É um trabalho árduo você construir essa identidade de marca ao longo do tempo (Analista Sênior de Brand Marketing).

A empresa possui um canal de comunicação direto com o cliente, chamado de "Customer Service" que possui engenheiros como atendentes para buscar a solução rápida de um possível problema para o cliente. Os entrevistados mostraram que o fato do relacionamento ser tão próximo com o cliente, faz com que ele procure diretamente o comercial da empresa, ou até mesmo o especialista de produto para resolver um possível problema. Além disso, a empresa mantém um site chamado New Holland Tools em que os concessionários, através de senha, têm acesso a todo tipo de material publicitário da marca para reproduzir para seus clientes. A empresa também está presente nas redes

sociais, como Facebook, Linkedin, Twiter e Youtube, com posts diários e acompanhamento do que é dito e perguntado, com o objetivo de interagir com os seguidores e não somente expor conteúdos.

No que se refere às ações realizadas com clientes para incentivo das vendas, destacou-se que a empresa oferece condições comerciais diferenciadas nas feiras de construção que acontecem no país e nos eventos realizados pela própria marca, como o "Yellow Day". Como já explorado anteriormente, a empresa também possui o "Teste e Comprove", onde o cliente fica utilizando a máquina por um tempo nas suas próprias atuações, para identificar se existe a necessidade da compra da máquina. Existe também o já citado "Yellow Club" que permite ações diferenciadas para os quarenta principais clientes da marca.

Através das entrevistas, foi possível identificar o discurso que é exercido pela New Holland. Percebeu-se uma tentativa de humanização da marca por meio do discurso, com o objetivo de aproxima-la das pessoas, sendo clientes em potencial ou não, reforçando o posicionamento da marca, como comenta a Analista Sênior de Brand Marketing:

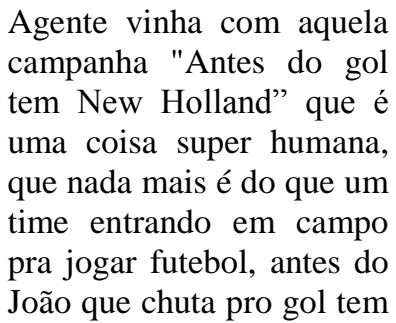


a New Holland que constrói as pontes que chegam ao estádio, que ergue o campo de futebol, levanta as arquibancadas e etc. Ou seja, esse discurso de tentar mostrar que a marca é mais do que uma máquina que levanta tijolo, é uma máquina que trabalha para melhorar a qualidade de vida das pessoas, para desenvolver um país e gerar qualidade de vida. Isso tudo está amarrado ao nosso posicionamento: é uma marca próxima do cliente.

\subsection{Análise das Entrevistas}

Após apresentar os resultados obtidos através das entrevistas, é preciso confrontar o que foi dito com a teoria na qual o estudo está ancorado. Desta forma, foi possível perceber que a empresa está interessada em promover seu nome e deixar claros os benefícios que são oferecidos aos clientes, sejam eles funcionais, emocionais ou de alta expressão, a partir do momento em que eles associam a sua imagem pessoal ou de empresa, no caso de clientes corporativos, com os produtos e também com a imagem fornecida pela New Holland, como dito por Kotler (1998). Segundo o autor, promover o reconhecimento da marca gera maior participação e credibilidade de mercado à empresa.

A empresa utiliza a marca com um ativo estratégico e busca, através do reconhecimento da marca, ganhar cada vez mais vantagem competitiva no mercado de máquinas de construção, diferenciando seus produtos dos demais concorrentes, conforme dito por Aaker (1998). Quando a empresa investe em uma personalidade de marca "amiga" dos seus clientes, através da proximidade que é fortemente promovida, a empresa busca cumprir as duas principais funções da marca, conforme dito por Aaker e Joaquimsthaler (2002), criando uma proposta de valor relevante e fazendo com que essa proposta adquira credibilidade no mercado.

É possível perceber nos relatos feitos pelos entrevistados que os clientes, ao participar dos eventos promovidos pela marca compreendem não só os atributos funcionais dos produtos, mas também adquirem percepções e sentimentos diferenciados com relação a esses atributos e à marca. Segundo Keller (2007), todas essas dimensões são adicionadas aos produtos e os diferenciam dos produtos concorrentes. A empresa realiza esses eventos para agregar valor a seus produtos e como disse Silveira (2008), com o propósito de influenciar na decisão de compra de seus clientes. Ao se relacionar de maneira tão aberta e próxima a seus clientes, a empresa busca controlar ao máximo as sensações e sentimentos que ao atingir o receptor se transformam em um conceito psicológico, porém, para Baker (2005), esse conceito não pode ser completamente controlado, uma vez que contará com as experiências e emoções únicas de cada indivíduo.

Com a mudança ocorrida em 2005, no momento em que a marca New Holland 
surge, migrando de outras marcas que já possuíam imagem e identidade formadas, várias estratégias foram adotadas com $\mathrm{o}$ objetivo de reconstruir na nova marca, todas as emoções e percepções que eram transmitidas pela marca anterior. Esse foi um momento crítico que exigiu e ainda se mostra necessário, trabalho intenso dos gestores para promover a nova marca, agregando a ela as características que faziam a antiga Fiatallis no Brasil, ser tão potente e reconhecida. Todo esse trabalho de construção da marca é afirmado por Kotler (2000), quando o autor afirma que a arte do marketing é, em sua maior parte, a arte de construir marcas.

$\mathrm{O}$ interesse da empresa em fortalecer a sua marca se mostra também à recomendação de ações nesse sentido no contexto B2B, conforme Aaker (1998). A marca, a partir do momento em que está fortalecida, pode inclusive ajudar na estratégia de aumento do preço que a empresa pretende ajustar futuramente, uma vez que foi dito que o valor oferecido aos clientes através do produto é maior do que o preço que eles pagam por ele. Sendo assim, a empresa conseguiria aumentar o seu preço, na medida em que seu brand equity se mostre cada vez mais fortalecido, de forma semelhante ao que acontece com marcas de mercadorias finais.

O fato de a empresa utilizar todas as formas de comunicação citadas por Churchill e Peter (2000) no mix de comunicação propaganda, venda pessoal, promoção de vendas e publicidade - demonstra que existe o interesse de construir uma imagem condizente com a identidade da marca (VASQUEZ, 2007).

Dessa forma, respondendo à pergunta de pesquisa proposta, para fazer a gestão da marca, a empresa se preocupa em fortalecer todas as suas bases no mix de marketing, com produtos de qualidade e com diferenciais consideráveis para seus concorrentes, com uma capilaridade que atinge todo o mercado brasileiro, com preços que não refletem as qualidades oferecidas, mas que condizem com o mercado, e com atuação em todas as frentes da comunicação. Esse fortalecimento se faz necessário devido à transição de marca ocorrida no ano de 2005, a participação da empresa no mercado brasileiro se abalou e foi preciso reconstruir as estratégias de gestão da marca para recuperar a imagem e identidade usadas anteriormente.

\section{CONSIDERAÇÕES FINAIS}

A primeira categoria apresentou os principais segmentos de atuação da empresa, que são construção, rental e Governo. Foi possível perceber também que a New Holland tem alta capacidade de adaptação às mudanças de mercado, seja fazendo adaptações pontuais nas máquinas ou até mesmo procurando atuar de forma mais efetiva em mercados pouco explorados para 
superar momentos de crise no país, essa característica foi adquirida em um momento de transição da marca Fiatallis para New Holland, quando foi preciso se adaptar rapidamente às mudanças do mercado para conseguir penetrar no mercado brasileiro.

Ainda na primeira categoria, percebeuse como estratégia de aumentar participação no mercado o fato da empresa investir no mercado agrícola, ainda pouco explorado pela mesma. Além disso, a empresa procura fazer adaptações pontuais na maquina, visando adequa-la a funções diferentes, o que ajuda a ganhar mercados diferentes. A marca é a terceira maior em participação de mercado. $\mathrm{Na}$ segunda categoria verificou-se que a empresa possui grande Know-how de tecnologia, inovação, vanguarda e confiabilidade. A preocupação da empresa é fazer produtos com qualidade, performance, produtividade e baixo consumo. Destaca-se também o pós-vendas realizado pelos concessionários, fornecendo peças e serviços de apoio aos proprietários das máquinas. Os produtos ainda possuem alguns atributos ergonômicos que não são encontrados nos produtos concorrentes, como a cabine com visibilidade melhor e fácil acesso a manutenção diária. Os entrevistados ainda relataram que a marca possui mais valor agregado do que é refletido pelo preço, pois os produtos são de qualidade, a assistência técnica está sempre à disposição, além de ser uma marca forte que demonstra confiabilidade. Porém, modificar o preço exige bastante cuidado e tempo, para alinhar a qualidade oferecida com a necessidade do mercado. Destaca-se que houve uma compatibilidade da adaptação de produto e preço às demandas por segurança em marcas no contexto B2B (KOTLER E PFOERTSCH, 2008).

A terceira categoria mostrou que entre a empresa e o cliente final estão localizados os concessionários que são considerados parceiros da marca e intermediam as relações entre os extremos. Verificou-se também que a empresa possui forte vínculo com seus clientes e que o marketing de relacionamento é o diferencial da marca, uma vez que pratica várias ações com o intuito de se aproximar dos clientes. Dentre essa ações estão os eventos, como o "Yellow Day" e o "Yellow Night" que procuram estreitar a relação da marca com os clientes. A empresa também possui o "Yellow Club" que direciona ações diferenciadas para os quarenta principais clientes da marca.

A quarta categoria mostrou que a empresa realiza um plano de mídia publicitária anualmente, atuando em várias frentes, como na mídia segmentada, através da assessoria de imprensa, em veículos como jornais e revistas especializados no segmento de construção. A empresa também atua nas mídias de massa através de rádios, revistas, jornais e programas de televisão, como o Globo Rural, da emissora Globo. A empresa 
utiliza recursos como mala direta, folhetos e e-mail marketing para atingir o público-alvo. Além disso, a empresa possui um canal de comunicação direto com os clientes chamado Customer Service com o objetivo de resolver eventuais problemas nas máquinas dos clientes.

Foi possível perceber através das entrevistas que a empresa realiza ações de incentivos de vendas, como condições comerciais diferenciadas em eventos e feiras do setor. Existe também o Teste e Comprove, onde o cliente fica utilizando a máquina nas suas próprias atuações para testa-la. O discurso apresentado pela empresa tem a intenção de humanizar a marca, com o objetivo de aproxima-la das pessoas em geral, reforçando o posicionamento de marca próxima ao cliente.

Dessa forma, respondendo à pergunta de pesquisa proposta, para fazer a gestão da marca, a empresa se preocupa em fortalecer todas as suas bases no mix de marketing, com produtos de qualidade e com diferenciais consideráveis para seus concorrentes, com uma capilaridade que atinge todo o mercado brasileiro, com preços que não refletem as qualidades oferecidas, mas que condizem com o mercado, e com atuação em todas as frentes da comunicação. Esse fortalecimento se faz necessário devido à transição de marca ocorrida no ano de 2005, a participação da empresa no mercado brasileiro se abalou e foi preciso reconstruir as estratégias de gestão da marca para recuperar a imagem e identidade usadas anteriormente. Destaca-se, ainda, que as estratégias da empresa de adequação do Mix de Marketing, e consequentemente para o fortalecimento de sua marca, parecem coerentes às orientações da literatura no marketing B2B (KOTLER, 2000; BAKER, 2005).

Ressalta-se que estudo baseou-se apenas na visão da empresa sobre a estratégia, dessa forma, os resultados encontrados apenas apresentam o que é feito pela empresa para fazer a gestão de marca, não se atendo em observar os outros âmbitos que comprovam a eficiência da estratégia, como a visão dos clientes com relação ao valor percebido da marca, ou ainda uma análise específica do mercado de equipamentos de construção. Portanto, outra possibilidade para futuros estudos se dá através da análise de outras perspectivas, sendo a perspectiva do cliente ou a perspectiva de comparações entre as principais marcas do mercado de equipamentos de construção.

\section{REFERÊNCIAS BIBLIOGRÁFICAS}

AAKER, D. Criando e administrando marcas de sucesso. São Paulo: Futura, 1996.

AAKER, D. A. Managing Brand Equity: capitalizing on the value of a brand name. New York: The Free Press, 1991.

AAKER, D. A. Marcas: brand equity: gerenciando o valor da marca. 10th. ed. São Paulo: Elsevier, 1998. 
AAKER, D. A. JOACHIMSTALER, E. Como Construir Marcas Líderes. Porto Alegre: Bookman, 2007.

BAKER, M. J. Administração de Marketing. Rio de Janeiro: Editora Campus, 2005.

BAUER, M.; GASKELL, G. Pesquisa qualitativa com texto, imagem e som. Petrópolis: Vozes, 2002.

CHURCHILL, G.; PETER, P. J. Marketing: criando valor para os clientes. 2. ed. São Paulo: Saraiva, 2000.

COLAUTO, R. D.; BEUREN, I. M.; MECCA, M. S.; PINHEIRO, L. E. T. Identificação de Canais de Comunicação Mercadológica Utilizados Como Mecanismos Para Delineamento do Planejamento Estratégico. Revista Contexto, Porto Alegre, v.6, n.9, p. 1-23, 2006. Disponível em: $<$ http://seer.ufrgs.br/ConTexto >. Acesso em: 01 maio 2015.

COSTA, A.R.; CRESCITELLI, E. Marketing Promocional Para Mercados Competitivos. São Paulo, Atlas: 2003.

FACHIN, O. Fundamentos de metodologia. São Paulo: Saraiva, 2001.

FLICK, U. Uma introdução à pesquisa qualitativa. 2. ed. Porto Alegre: Bookman, 2014.

GRÖNROOS, C. Service Management and Marketing: customer management in service competition. 3th. ed. Chichester: John Wiley \& Sons, 2007

GUENZI, P. TROILO, G., (2006), Developing Marketing Capabilities For Customer Value Creation Through Marketing-sales integration. Industrial Marketing Management, vol. 35, pp. 974988.

KELLER, K. L. Strategic brand management: building, measuring and managing brand equity. New Jersey:Prentice-Hall, 1998.
KELLER, K. L.; MACHADO, M. Gestão Estratégica De Marcas. São Paulo: Pearson Prentice Hall, 2007.

KOTLER, P. Administração de marketing: análise, planejamento, implementação e controle. 5. ed. São Paulo: Atlas, 1998.

KOTLER, P. Administração de Marketing: a edição do novo milênio. 10th. ed. São Paulo: Prentice Hall, 2000.

KOTLER, P.; PFOERTSCH, W. Gestão de marcas em mercados B2B. Porto Alegre: Bookman, 2008.

KOTLER, P.; ROBERTO, E. Marketing Social: estratégias para alterar o comportamento público. Rio de Janeiro: Campus, 1992.

LEITE, R. C.; WINCK. C. A.; ZONIN, V. J. A. A Influência do Estrangeirismo no Processo de Construção da Marca no Agronegócio. Brazilian Business Review, Espírito Santo, v.9, n.1, p. 110-133, jan./mar. 2012. Disponível em:

$<$ http://bbronline.com.br/artigos.asp? sessao $=$ r eady\&cod_artigo $=237>$. Acesso em: 14 agosto 2015 .

MAANEM, J. V. Reclaiming qualitative methods for organization research: a preface. Administrative Science Quaterly, v. 24, n.4, p.520-526, 1979.

MALHOTRA, N. Pesquisa de marketing: uma orientação aplicada. 5. ed. Porto Alegre: Bookman,2004.

PRIDE, W. M.; FERREL, O. C. Marketing: conceitos e estratégias. 11. ed. São Paulo: LTC Editora, 2001.

SCIASCI, V.; GARCIA, S. F. A.; GALLI, L. C. L. A. Posicionamento de Marcas Globais: um estudo bibliométrico da produção científica na área. Revista Brasileira de Marketing, São Paulo, v.11, n.2, p. 67-93, mai./ago. 2012. Disponível em: 
<http://www.revistabrasileiramarketing.org/oj s-2.2.4/index.php/remark/article/view/2332>. Acesso em: 14 agosto 2015.

SILVEIRA, P. A. B. A Influência da Marca no Ambiente Organizacional. Revista Administração em Diálogo, São Paulo, v.10, n.1, p. 140-160, 2008. Disponível em: < http://revistas.pucsp.br/index.php/rad/article/v iew/2127 > . Acesso em: 13 agosto 2015.

Sobre o Top Of Mind. Instituto de Pesquisa Datafolha. Disponível em:

<http://datafolha.folha.uol.com.br/produtos/to pofmind/> . Acesso em: 28 agosto 2015.

TONI, D.; BACICHETTO, V. V.; MILAN, G. S.; LARENTIS, F. A Relação entre Conhecimento da Marca e Nível de Preço na Intenção de Compra: um experimento com perfumes de luxo. Revista Brasileira de Marketing, São Paulo, v.13, n.3, p.108-124, abr./jun. 2014. Disponível em: <

http://www.revistabrasileiramarketing.org/ojs -2.2.4/index.php/ remark/article/view/2546/pdf_160>. Acesso em: 19 agosto 2015.

VÁSQUEZ, R. P. Identidade de Marca, Gestão e Comunicação. Revista Brasileira de Comunicação Organizacional e Relações Públicas, São Paulo, v.4, n.7, p. 198-211, 2007. Disponível em: <http://www.revistaorganicom.org.br/sistema/ index.php/organicom/article/ view/119/138>. Acesso em: 18 agosto 2015. 